\title{
Increased Expression of Renal Cyclooxygenase-2 and Neuronal Nitric Oxide Synthase in Hypertensive Cx40-Deficient Mice
}

\author{
Nathalie Krattinger ${ }^{a}$ Florian Alonso $^{a} \quad$ Alessandro Capponi $^{b} \quad$ Lucia Mazzolai $^{a}$ \\ Pascal Nicod $^{a}$ Paolo Meda ${ }^{c}$ Jacques-Antoine Haefliger ${ }^{a}$ \\ a Department of Medicine, University Hospital, Lausanne, ${ }^{b}$ Department of Internal Medicine, \\ University of Geneva, School of Medicine, HUG, and ' Department of Cell Physiology and Metabolism, \\ University of Geneva, School of Medicine, CMU, Geneva, Switzerland
}

\section{Key Words}

Gap junctions $\cdot$ Connexins $\cdot$ Transgenic mice $\cdot$ Kidney •

Hypertension · Secretion

\begin{abstract}
Cx40-deficient mice ( $\mathrm{C} 40-/-)$ are hypertensive due to increased renin secretion. We evaluated the renal expression of neuronal nitric oxide synthase (nNOS) and cyclooxygenases COX-1 and COX-2, three macula densa enzymes. The levels of nNOS were increased in kidneys of Cx40-/- mice, as well as in those of wild-type (WT) mice subjected to the twokidney one-clip model of hypertension. In contrast, the levels of COX-2 expression were only increased in the hypoperfused kidney of $\mathrm{Cx} 40-/-$ mice. Treatment with indomethacin lowered blood pressure and renin mRNA in Cx40-/- mice without affecting renin levels, indicating that changes in COX-2 do not cause the altered secretion of renin. Suppression of NOS activity by $\mathrm{N}^{\mathrm{G}}$-nitro-L-arginine methyl ester (L-NAME) decreased renin levels in Cx40-/- animals, indicating that NO regulates renin expression in the absence of $\mathrm{Cx} 40$. Treatment with candesartan normalized blood pressure in Cx40-/- mice, and decreased the levels of both COX2 and nNOS. After a treatment combining candesartan and L-NAME, the blood pressure of $C \times 40-/-$ mice was higher than that of WT mice, showing that NO may counterbalance the vasoconstrictor effects of angiotensin II in Cx40-/- mice.
\end{abstract}

These data document that renal COX-2 and nNOS are differentially regulated due to the elevation of renin-dependent blood pressure in mice lacking Cx40.

Copyright $\odot 2008$ S. Karger AG, Basel

\section{Introduction}

Prostaglandins affect the function of macula densa and renin cells in hypertension [1-4]. The renal cyclooxygenases COX-1 and COX-2 are the rate-limiting enzymes in their synthesis [2]. COX-1 is constitutively expressed in smooth muscle of renal vessels and in the collecting ducts of the renal medulla $[5,6]$, whereas COX-2 is mainly localized in the macula densa, the thick ascending limb of the loop of Henle and the interstitial cells of the medulla [6, 7]. Due to this distribution, COX-2 triggers the formation of prostanoids, which promote the expression and secretion of renin by the cells of the neighboring juxtaglomerular apparatus (JGA) [8]. Accordingly, the expression of COX-2 is increased in the renal cortex under several conditions of increased renin production [5, 9-12], indicating a tight coordination between the expression of the two enzymes. Nitric oxide (NO) is anoth-

N. Krattinger and F. Alonso contributed equally to this work.

\section{KARGER}

Fax +41613061234 E-Mail karger@karger.ch www.karger.com
(C) 2008 S. Karger AG, Basel

$1018-1172 / 09 / 0463-0188 \$ 26.00 / 0$

Accessible online at:

www.karger.com/jvr
PD Dr. Jacques-Antoine Haefliger

Department of Internal Medicine, Laboratory of Molecular Medicine 19-135S

University Hospital, CHUV, CH-1011 Lausanne (Switzerland)

Tel. +4121314 0926, Fax +41213140968

E-Mail Jacques-Antoine.Haefliger@chuv.ch 
er tonic stimulator of renin expression which, under physiological conditions, is counteracted by angiotensin II [13] and contributes to regulating the macula densa [14]. Under a variety of conditions, the expression of neuronal nitric oxide synthase (nNOS) and COX-2 changes in parallel with that of renin even though the expression of the nNOS and COX-2 genes may not be interdependently regulated [15-19].

Recent studies have shown that the signaling due to connexins $(\mathrm{Cx})$ is an important mechanism in the multifactorial coordination of JGA cells and renin secretion [20-28]. The renin-secreting cells (RSCs) of the JGA form gap junction channels made of $\mathrm{Cx} 40$ and $\mathrm{Cx} 37$ [23, 29, $30]$. We and others recently demonstrated that mice lacking Cx40 [31-34] feature excessive renin production and secretion, leading to sustained activation of the renin-angiotensin system [35-38]. Cx40 is ideally located to detect blood-borne signals and to propagate them across renal vessels and the RSCs of the JGA [24], thus permitting the integration of the mechanical, hormonal and ionic inputs that control blood pressure [20,38].

So far, however, no study has investigated whether and how Cx40-dependent signaling may interact with signaling dependent on prostaglandins and/or NO, which play a role in the in vivo control of hypertension. To address this question, we compared the renal expression of COX$1, \mathrm{COX}-2$ and nNOS in the kidneys of hypertensive $\mathrm{Cx} 40$ null mice and their control littermates, and tested the effects of drugs blocking the activity of these key enzymes.

\section{Methods}

\section{Knock-Out Mice}

Breeding pairs of $\mathrm{Cx} 40-/-$ mice [31] originally provided by Dr. K. Willecke were crossed with control C57Bl6 partners. Identification of the wild-type $(\mathrm{Cx} 40+/+)$, and homozygous $\mathrm{Cx} 40-/-$ mice was performed by PCR of genomic DNA, using the following primers: for the $\mathrm{Cx} 40 \mathrm{WT}$ allele (314 bp), 5'-GGGAGATGAGCAGGCCGACTTCCGGTGCG-3' (sense) and 5'-GTAGGGTGCCCTGGAGGACAATCTTCCC-3' (antisense); for the Cx40 recombinant allele (494 bp), 5'-GGATCGGCCATTGAACAAGATGGATTGCAC-3' (sense) and 5'-CTGATGCTCTTCGTCCAGATCATCCTGATCG-3' (antisense). Three- to four-monthold mice, from litters obtained after at least 10 backcrosses into the C57/Bl6 background, were used in all the experiments [31, 37].

\section{Animal Experiments}

Mouse care, surgery and euthanasia procedures were approved by our institutional committee for animal experiments and State of Vaud Veterinary Office. Groups of animals were submitted to one of the following experiments: (1) hypertension was induced for 4 weeks by the two-kidney, one-clip (2K1C) procedure [30, 37]; (2) the renin-angiotensin system was blocked by adding $3 \mathrm{mg} /$ $\mathrm{kg} \cdot$ day of the $\mathrm{AT}_{1}$-receptor antagonist candesartan $\left(\right.$ Cilexetil ${ }^{\circledR}$; AstraZeneca) to the drinking water for 2 weeks [37]; (3) the function of the macula densa was modulated by feeding a diet (Kliba, Switzerland) containing either $0.03 \%$ (low-salt group), $4 \%$ (highsalt group) or $0.3 \% \mathrm{NaCl}$ (control group) for 3 weeks [11]. All mice had free access to tap water. (4) To inhibit prostaglandins, mice were injected intraperitoneally with $3 \mathrm{mg} / \mathrm{kg} \cdot$ day the nonselective COX inhibitor indomethacin (Indocin ${ }^{\circledR}$; Merck) for 3 successive days. Control mice were similarly injected with $0.9 \% \mathrm{NaCl}$. Animals were studied at the end of the 3-day period. (5) To inhibit $\mathrm{NO}$, the mice received $80 \mathrm{mg} / \mathrm{kg} \cdot$ day L-NAME (Sigma Chemical Co.) in the drinking water for 3 weeks [39]. The L-NAME solution was made fresh every 3 days; (6) L-NAME was also added in drinking water in combination with candesartan. In this case, 2 weeks after treatment with $3 \mathrm{mg} / \mathrm{kg}$-day candesartan, when the blood pressure of $\mathrm{Cx} 40-/-$ mice had returned to control values, $80 \mathrm{mg} / \mathrm{kg} \cdot$ day L-NAME were added to the candesartan solution for another 2 weeks [40].

Mean blood pressure was measured by an invasive method $[30,37]$. One day before sacrifice, a catheter connected to a pressure transducer was inserted into the right carotid artery of anesthetized mice. The next day, a computerized data acquisition system was used to record the heart rate every $20 \mathrm{~s}$ as well as the diastolic and systolic intra-arterial pressures of the conscious mice $[30,41]$. After a 30 -min recording period, $300 \mu \mathrm{l}$ blood was collected in EDTA-coated tubes and centrifuged at $4^{\circ} \mathrm{C}$. Plasma was stored at $-70^{\circ} \mathrm{C}$ until use. In some experiments, mean blood pressure and pulse rate were also monitored in mice pretrained for 7 days, by a noninvasive computerized tail cuff method (BP-2000; Visitech Systems). Data are shown as the mean of the diastolic and systolic values.

Measurements of Plasma Renin Activity

Plasma renin activity was measured by a radioimmunoassay based on angiotensin I trapping by an antibody [30, 37].

RNA Analysis

Kidneys were homogenized in Tripure Isolation Reagent (Roche, Switzerland), using a Kinametic polytron blender (Kinametica, Switzerland). RNA isolation was performed as described [30]. Quantitative real-time PCR was performed on total RNA treated for $30 \mathrm{~min}$ in the presence of DNase I (DNA-free kit; Ambion, Cambridge, UK), using a LightCycler Instrument (Roche Diagnostics GmbH, Mannheim, Germany) and the QuantiTect SYBR Green PCR Kit (Qiagen, Basel, Switzerland) [30]. Negative controls included amplification of distilled water, and RNA samples that had not been reverse transcribed. Analysis of data was performed using the 3.5 version of the Light Cycler software (Roche Diagnostics $\mathrm{GmbH}$ ). cDNAs were amplified using the following mouse primers: for COX-2 (239 bp): 5'-ACAACAACTCCATCCTCCTG-3' (sense) and 5'-AGCCATTTCCTTCTCTCCTG-3' (antisense); for COX-1 (209 bp): 5'-GTGGCTATTTCCTGCAGCTC-3' (sense) and 5'-CAGTGCCTCAACCCCATAGT3' (antisense); for renin (158 bp): 5'-TCTCTGGGCACTCTTGTTGCTCTG-3' (sense) and 5'-ATACGTCCCATTCAGCACTGAGCC-3' (antisense); for nNOS (222 bp): 5'-CAACAGCGTCTCCTCCTATTCT-3' (sense) and 5'-TCATCTCCCTCCCT- 
CATCTT-3' (antisense); for GAPDH (334 pb): 5'-GACTCCACGACATACTCAGC-3' (sense) and 5'-GTCGGTGTGAACGGATTTGG-3' (antisense).

\section{Immunodetection of COX and $n N O S$}

Kidney fragments were frozen in 2-methylbutane previously cooled in liquid nitrogen. Cryostat sections were immunostained [30] using polyclonal antibodies against either COX-2 (160126; Cayman Chemical Co.), or nNOS (610310; BD Transduction Laboratories) both diluted 1:100. Binding sites of COX-2 and nNOS antibodies were visualized using an avidin-biotinylated horseradish peroxidase complex (Vectastain Elite ABC Kit; Vector Laboratories, Inc., Burlingame, Calif., USA), diluted 1:50 [42]. After rinsing in PBS, the product of the peroxidase reaction was visualized using $0.1 \%$ 3,3-diaminobenzidine tetrahydrochloride dehydrate, dissolved in PBS containing $0.3 \% \mathrm{H}_{2} \mathrm{O}_{2}$. Reactions were stopped after 10-15 min to maximize signal intensity.

\section{Western Blotting}

Four mice per group were sacrificed and immediately infused with $15 \mathrm{ml}$ PBS. The kidneys were excised, rapidly placed into liquid nitrogen, reduced to powder, and stored at $-80^{\circ} \mathrm{C}$. Aliquots of $50 \mathrm{mg}$ kidney powder were homogenized by sonication in $1 \mathrm{ml}$ Passive Lysis Buffer (Promega). Total protein content was determined by the DC protein assay reagent kit (Bio-Rad Laboratories). Protein aliquots $(30 \mu \mathrm{g})$ were fractionated by electrophoresis in a $12.5 \%$ polyacrylamide gel, and transferred onto Immobilon-P membranes (Millipore Co.) at $75 \mathrm{~V}$. The following primary antibodies were used: rabbit polyclonal antibodies against COX-2 (160126; Cayman Chemical Co.) diluted 1:100, rabbit polyclonal antibodies against nNOS (160870; Cayman Chemical Co.) diluted 1:100; mouse monoclonal antibodies against $\alpha$-tubulin (T5168; Sigma) diluted 1:2,000. The secondary antibodies were sheep anti-rabbit immunoglobulin coupled to alkaline phosphatase (Bio-Rad Laboratories) for COX and nNOS detection, and rabbit anti-mouse immunoglobulin coupled to alkaline phosphatase (Bio-Rad Laboratories) for tubulin detection. Bands were developed using enhanced chemiluminescence (Amersham Biosciences). The densitometric levels of immunolabeled proteins were normalized relative to those of tubulin $[31,37]$.

\section{Statistical Analysis}

Results are presented as mean \pm SEM. Statistical comparisons between groups were performed by a one- or two-way analysis of variance, followed by a Newman-Keuls test, whichever was appropriate. Statistical significance was defined at a value of $\mathrm{p}<0.05$ or less.

\section{Results}

\section{Cx40-/- Mice Are Hypertensive due to Activation of} the Renin-Angiotensin System

Cx40-/- mice featured a $40 \%$ increase $(\mathrm{p}<0.001)$ in blood pressure (table 1$)$, and a 2 -fold increase $(\mathrm{p}<0.05)$ in kidney expression of renin mRNA (table 2) which resulted in a 20 -fold elevation $(p<0.001)$ of the circulating
Table 1. Characteristics of mice and plasma renin activity levels at the end of the experiment

\begin{tabular}{lrlll}
\hline Mice/Groups & $\mathrm{n}$ & $\begin{array}{l}\text { Body } \\
\text { weight, } g\end{array}$ & $\begin{array}{l}\text { MBP } \\
\mathrm{mm} \mathrm{Hg}\end{array}$ & $\begin{array}{l}\text { PRA } \\
\text { ng ANG I/ml·h }\end{array}$ \\
\hline WT & & & & \\
$\quad$ Normal salt & 10 & $28.5 \pm 1.7$ & $103 \pm 3$ & $2.00 \pm 0.80$ \\
Candesartan & 10 & $30.2 \pm 1.0$ & $107 \pm 3$ & $36.0 \pm 8.00^{* * *}$ \\
Sham & 9 & $30.5 \pm 0.6$ & $104 \pm 4$ & $1.80 \pm 0.90$ \\
2K1C & 9 & $28.8 \pm 0.8$ & $142 \pm 6^{* *}$ & $14.0 \pm 4.00^{* * *}$ \\
Low salt & 9 & $25.4 \pm 0.9$ & $105 \pm 5$ & $8.00 \pm 1.00^{*}$ \\
High salt & 9 & $26.0 \pm 0.9$ & $104 \pm 4$ & $0.20 \pm 0.02^{*}$ \\
Indomethacin & 6 & $28.2 \pm 1.0$ & $98 \pm 4$ & $5.00 \pm 1.55$ \\
L-NAME & 6 & $27.5 \pm 0.9$ & $133 \pm 2^{* *}$ & $3.20 \pm 0.90$ \\
\hline Cx40-/- & & & & \\
Normal salt & 10 & $25.9 \pm 1.0$ & $154 \pm 3^{++}$ & $46.0 \pm 8.00^{++}$ \\
Candesartan & 12 & $31.6 \pm 2.5$ & $117 \pm 11^{* *}$ & $43.5 \pm 4.00$ \\
Sham & 11 & $26.3 \pm 1.6$ & $150 \pm 3$ & $52.0 \pm 13.0^{++}$ \\
2K1C & 11 & $28.2 \pm 0.6$ & $158 \pm 5$ & $51.0 \pm 10.0^{++}$ \\
Low salt & 10 & $26.0 \pm 2.8$ & $151 \pm 11$ & $60.0 \pm 13.0^{++}$ \\
High salt & 11 & $27.2 \pm 1.3$ & $154 \pm 4$ & $31.0 \pm 8.00^{*++}$ \\
Indomethacin & 6 & $30.2 \pm 1.2$ & $137 \pm 4^{* *+}$ & $42.2 \pm 9.00^{++}$ \\
L-NAME & 5 & $25.8 \pm 1.2$ & $167 \pm 5^{* *}$ & $34.2 \pm 8.00^{* *++}$ \\
\hline
\end{tabular}

$\mathrm{n}=$ Number of mice; sham = sham-operated mice; $\mathrm{MBP}=$ mean blood pressure; PRA = plasma renin activity. Values are expressed as mean $\pm \mathrm{SEM}$.

${ }^{*} \mathrm{p}<0.05,{ }^{* *} \mathrm{p}<0.01,{ }^{* * *} \mathrm{p}<0.001$, versus WT or Cx40-/- untreated or sham-operated animals; ${ }^{+} \mathrm{p}<0.001,{ }^{++} \mathrm{p}<0.001$, versus the respective WT animals.

levels of the enzyme (table 1). Treatment with candesar$\tan$ reduced $(\mathrm{p}<0.001)$ the blood pressure of $\mathrm{Cx} 40-/-$ mice to the levels observed in control littermates (table 1), without altering the levels of plasma renin (table 1) and renin mRNA (table 2). In contrast, the same treatment markedly increased $(\mathrm{p}<0.001)$ the renin levels of control mice (table 2).

\section{Renin Secretion Is Dysregulated in Cx40-/- Mice}

To evaluate the functioning of RSCs, mice were submitted to $2 \mathrm{~K} 1 \mathrm{C}$ surgery $[30,37]$. Four weeks later, blood pressure was increased $(\mathrm{p}<0.01)$ in WT mice, which showed elevated levels $(p<0.001)$ of circulating renin as a result of increased $(p<0.05)$ expression of the enzyme in the clipped kidney (table 1). Under the same conditions, the blood pressure and circulating levels of renin were unchanged in $\mathrm{Cx} 40-/-$ mice (table 1 ), which also showed unchanged levels of renin mRNA (table 2). 
Table 2. Renin mRNA levels at the end of the experiment

\begin{tabular}{lrll}
\hline Mice/Groups & $\mathrm{n}$ & \multicolumn{2}{l}{ Renin mRNA levels } \\
\cline { 2 - 4 } & & LK & RK \\
\hline WT & & \\
$\quad$ Normal salt & 10 & $1.01 \pm 0.05$ \\
Candesartan & 10 & $2.26 \pm 0.18^{*}$ & \\
Sham & 9 & $1.15 \pm 0.05$ & \\
2K1C & 9 & $1.73 \pm 0.19^{*}$ & $0.31 \pm 0.08^{* *}$ \\
Low salt & 9 & $1.60 \pm 0.13^{*}$ & \\
High salt & 9 & $0.80 \pm 0.07^{*}$ & \\
L-NAME & 10 & $0.48 \pm 0.04^{* *}$ & \\
Candesartan + L-NAME & 10 & $1.10 \pm 0.05$ & \\
\hline Cx40-/- & & & \\
Normal salt & 10 & $1.83 \pm 0.10^{+}$ & \\
Candesartan & 12 & $2.01 \pm 0.22$ & \\
Sham & 11 & $1.68 \pm 0.11^{+}$ & \\
2K1C & 11 & $1.99 \pm 0.38^{*,+}$ & $0.79 \pm 0.17^{*,+}$ \\
Low salt & 10 & $3.47 \pm 0.15^{*,++}$ & \\
High salt & 11 & $1.42 \pm 0.11^{*,+}$ & \\
L-NAME & 5 & $0.72 \pm 0.04^{*,++}$ & \\
Candesartan + L-NAME & 11 & $1.41 \pm 0.09^{+}$ & \\
\hline
\end{tabular}

$\mathrm{n}=$ Number of mice; sham = sham-operated mice. Values are expressed as mean \pm SEM.

${ }^{*} \mathrm{p}<0.05,{ }^{* *} \mathrm{p}<0.01$, versus WT or Cx40-/- untreated or sham-operated animals; ${ }^{+} \mathrm{p}<0.05,{ }^{++} \mathrm{p}<0.01$, versus the respective WT animals.

\section{Expression of COX-2 but Not COX-1 Is Altered in Cx40-/-}

The levels of COX-1 mRNA were similar in Cx40-/and control littermates, and were not modified by the $2 \mathrm{~K} 1 \mathrm{C}$ procedure or after treatment with candesartan (fig. 1A). In contrast, the transcript levels of COX-2 were markedly $(400 \%)$ higher $(\mathrm{p}<0.001)$ in $\mathrm{Cx} 40-/-$ than in WT littermates (fig. 1B). During 2K1C-induced hypertension, COX-2 mRNA levels increased in the clipped kidney, but not in the contralateral kidney of WT mice. In contrast, COX-2 mRNA levels were not modified in the clipped kidney of $\mathrm{Cx} 40-/-$ mice, and were reduced to control levels in the contralateral kidney (fig. 1B). Treatment with candesartan slightly increased $(\mathrm{p}<0.05)$ COX2 mRNA levels in WT mice, but decreased $(\mathrm{p}<0.01)$ these levels by $50 \%$ in the kidneys of $\mathrm{Cx} 40-/-$ animals (fig. 1B). Immunolabeling revealed that cells of the macula densa were more intensively stained for COX-2 in Cx40-/- than WT mice (fig. 1C). Western blot analysis confirmed that the former animals had 4 times more renal COX-2 than WT mice (fig. 1D). Under the conditions we tested, the levels of this protein changed (fig. 1D) in parallel with those of its transcript (fig. 1B).

After 3 weeks of salt restriction $(0.03 \% \mathrm{NaCl})$ or salt intake ( $4 \% \mathrm{NaCl})$, blood pressure was unchanged both in WT and Cx40-/- mice (table 1). The levels of renin circulating in the latter animals were significantly $(\mathrm{p}<$ 0.001 ) reduced by the high-salt diet (as in controls), but were still 15-fold higher than those measured in WT mice fed a normal salt diet (table 1). The decrease in plasma renin was paralleled by a downregulation of the renin transcript both in controls and in Cx40-/- littermates (table 2). Under these conditions, no change in COX-1 expression was observed in either type of mouse (fig. 2A). In contrast, COX- 2 expression changed with that of renin in WT mice, i.e. it was increased $(\mathrm{p}<0.05)$ in the mice fed a low-salt diet and decreased $(\mathrm{p}<0.05)$ in those receiving a high-salt diet. These changes were not seen in Cx40-/- mice (fig. 2B).

\section{Blockade of Prostaglandin Production Reduces the Blood Pressure of Cx40-/- Mice}

In view of the parallel increase in COX-2 and renin expression in $\mathrm{Cx} 40-/-$ mice, we investigated the role of prostaglandins in renin production. For this purpose, mice were treated with the nonselective COX inhibitor indomethacin. The drug slightly lowered $(\mathrm{p}<0.01)$ the blood pressure of $\mathrm{Cx} 40-/-$ mice but not of WT mice (fig. 3A). Exposure to indomethacin did not affect renin expression in control animals, but markedly reduced it to control levels in Cx40-/- mice (fig. 3B). However, no parallel decrease in plasma renin levels was observed (table 1). Indomethacin also increased COX-2 expression $(\mathrm{p}<0.001)$ and COX-1 $(\mathrm{p}<0.05)$ levels both in WT and their Cx40-/- littermates (fig. 3C, D).

\section{nNOS Expression Is Increased in Cx40-/- Mice}

In the kidneys of $\mathrm{Cx} 40-/-$ mice, the levels of nNOS were about 2 -fold higher $(\mathrm{p}<0.01)$ than in those of their WT littermates, whether evaluated at the transcript (fig. 4A) or protein level (fig. 4B). Four weeks after 2K1C surgery, nNOS mRNA levels were increased about 2 -fold both in the hypoperfused and the contralateral kidney of WT animals (fig. 4A), a change which was significantly smaller $(\mathrm{p}<0.01)$ than that seen in Cx40-/- mice. Candesartan did not alter nNOS expression in WT mice, but decreased that in Cx40-/- mice to control levels (fig. 4A). In both $\mathrm{Cx} 40-/-$ and WT mice, immunolabeling revealed nNOS in macula densa cells; immunolabeling intensity was somewhat higher in $\mathrm{Cx} 40-/-$ than in WT mice (fig. 4C). 

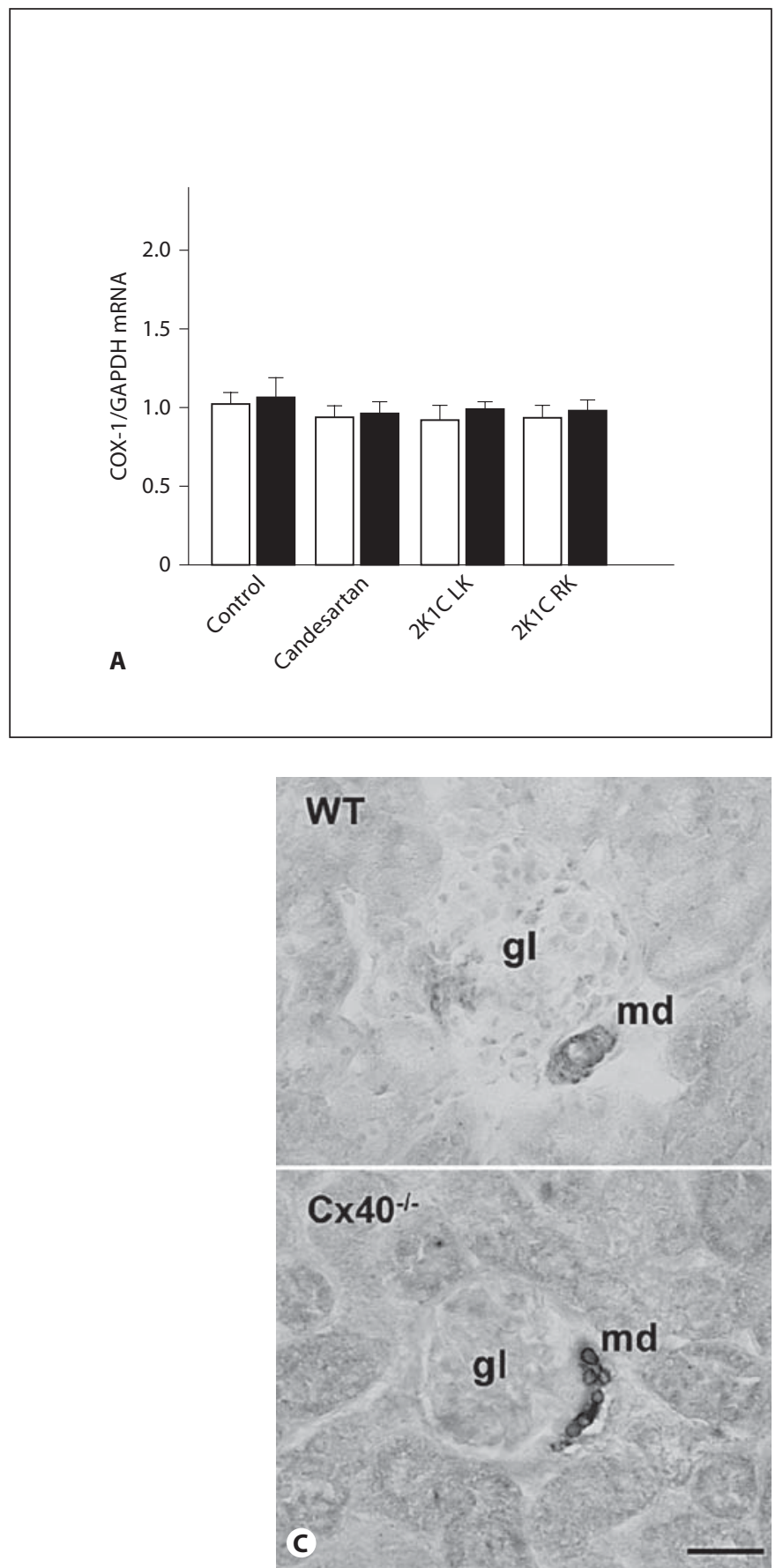

Fig. 1. COX-2 expression is increased in the kidneys of Cx40-/mice. $\mathrm{LK}=$ Left kidney; RK = right kidney. $\mathbf{A} \mathrm{WT}$ (open bars) and Cx40-/- mice (solid bars) expressed similar COX-1 levels under all the conditions tested. B In contrast, COX-2 expression was higher in Cx40-/- than in their WT littermates, and was differentially regulated in the two types of mice. C The intensity of COX-2 immunostaining in the macula densa (md) was higher in
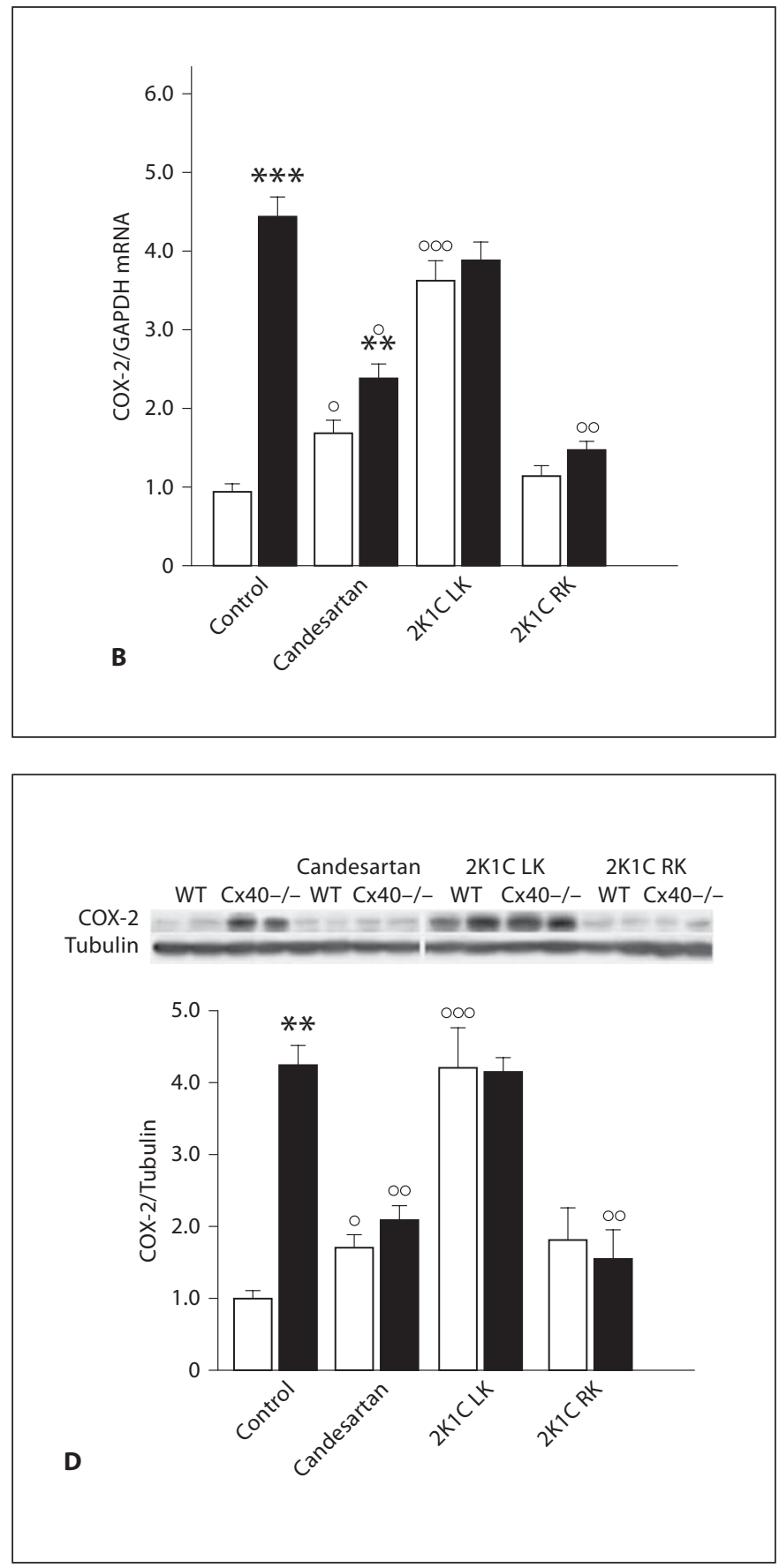

Cx40-/- than WT mice. gl = Glomerulus. Bar: $150 \mu \mathrm{m}$. D Western blot showed that the levels of COX-2 protein were 4 -fold higher in Cx40-/- than in WT mice, and changed under different experimental conditions as the cognate transcript. Data represent mean \pm SEM values of the number of mice specified in table $1 .{ }^{* *} \mathrm{p}<$ $0.01,{ }^{* * *} \mathrm{p}<0.001$, compared to WT; ${ }^{\circ} \mathrm{p}<0.05,{ }^{\circ \circ} \mathrm{p}<0.01,{ }^{\circ \circ} \mathrm{p}<$ 0.001 , compared to controls. 
Fig. 2. Salt diets reveal an abnormal regulation of COX-2 expression in $\mathrm{Cx} 40-/-$ mice. A Different salt loads did not change COX-1 expression in either WT (open bars) or Cx40-/- mice (solid bars). B In contrast, a low-salt diet (LS) increased COX-2 expression in WT mice, whereas a high-salt diet (HS) decreased this expression. These alterations were not observed in Cx40-/- animals. Data are mean \pm SEM values of the number of mice specified in table $1 .{ }^{* *} \mathrm{p}<0.01,{ }^{* * *} \mathrm{p}<0.001$, compared to WT; ${ }^{\circ} \mathrm{p}<0.05$ compared to control.

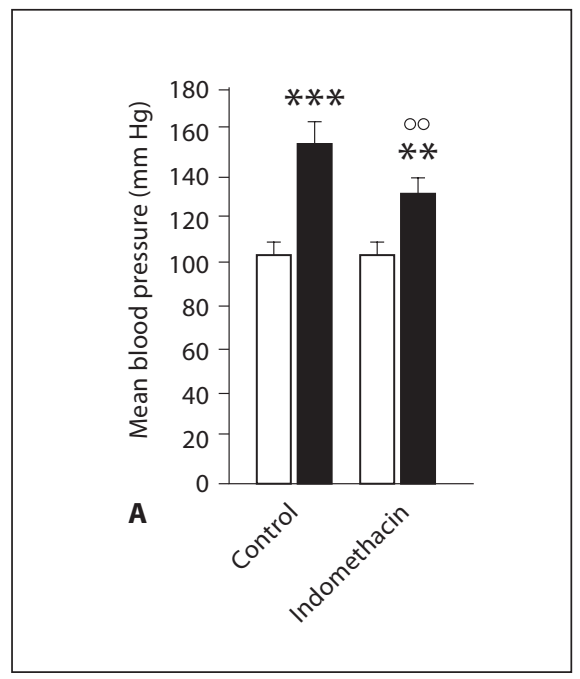

Fig. 3. Inhibition of COXs by indomethacin reduced the blood pressure of $\mathrm{Cx} 40-/-$ mice. A Indomethacin, a nonselective inhibitor of COXs, reduced blood pressure in Cx40-/- mice ( $\mathrm{n}=6$; solid bars) but not in control WT mice ( $n=6$; open bars). B After the indomethacin treatment, the renin mRNAs levels of Cx40-/- mice had decreased to the values observed in WT mice. These alterations were not observed in WT mice. C, D COX-1 and COX-2 mRNA levels were increased both in WT and Cx40-/- mice after treatment with indomethacin. ${ }^{* *} \mathrm{p}<0.01,{ }^{* * *} \mathrm{p}<0.001$, compared to WT; ${ }^{\circ} \mathrm{p}<0.05,{ }^{\circ \circ} \mathrm{p}<0.01,{ }^{\circ 0 \circ} \mathrm{p}<$ 0.01 , compared to controls.

COX-2 and NO Synthase in Cx40-/-

J Vasc Res 2009;46:188-198
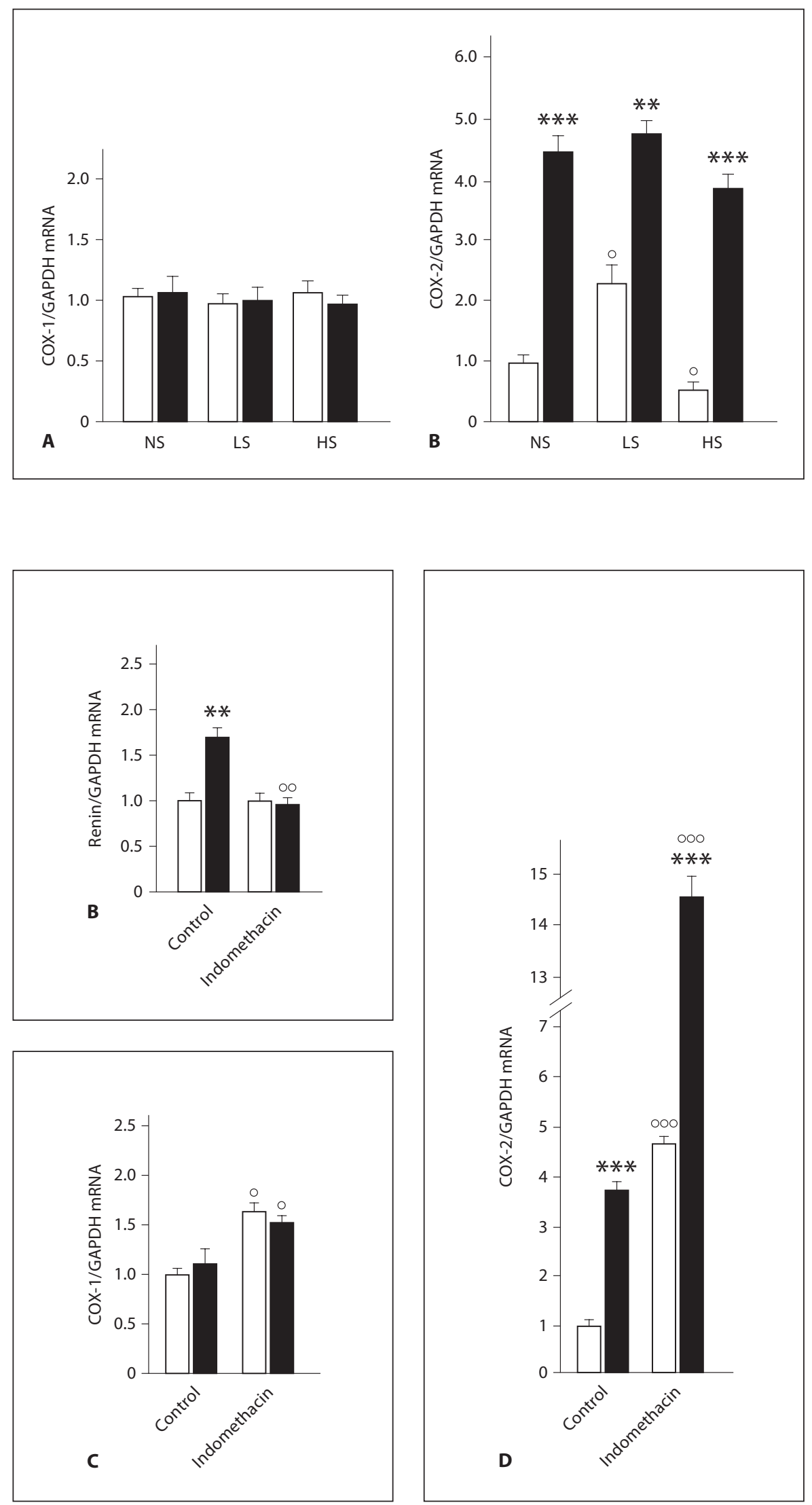


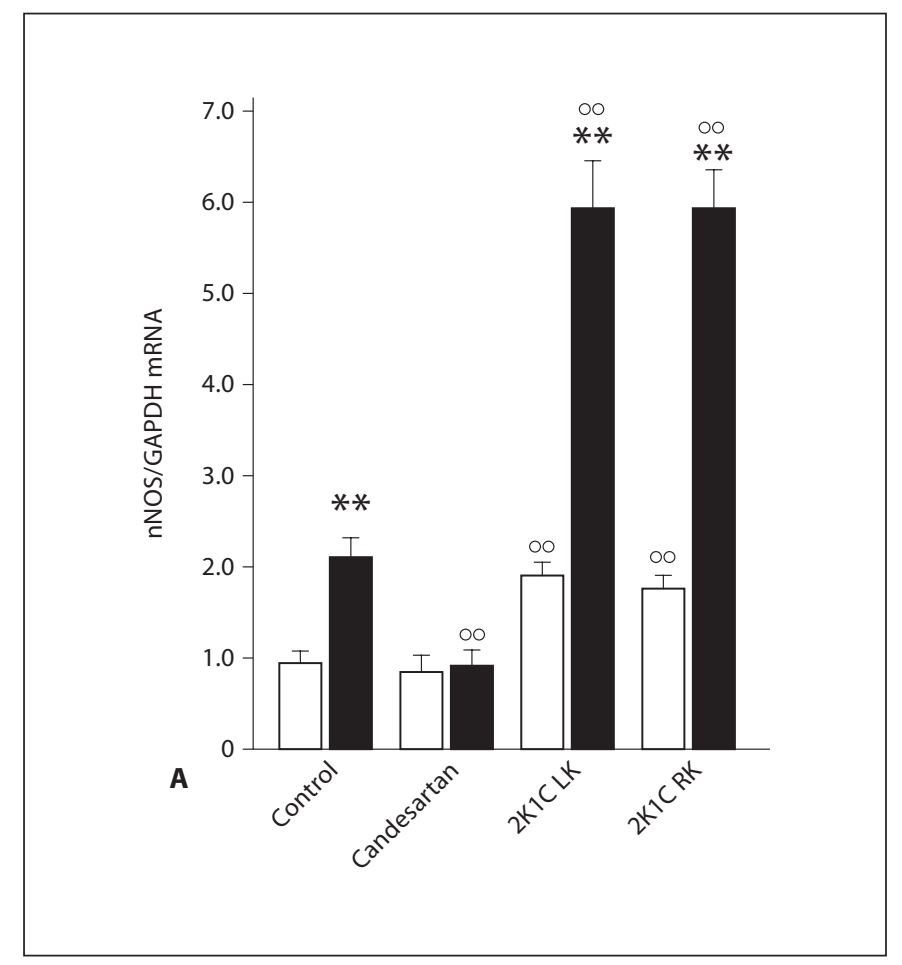

Fig. 4. $\mathrm{Cx} 40-/-$ mice feature increased expression of nNOS and abnormal regulation of this enzyme. A, B Renal nNOS mRNA (A) and protein (B) levels were higher in $\mathrm{Cx} 40-/-$ mice ( $\mathrm{n}=10$; solid bars) than in their WT littermates ( $n=10$; open bars). Treatment with candesartan decreased nNOS mRNA levels in the kidneys of Cx40-/- mice but not in those of WT controls. In both mouse genotypes, nNOS mRNA levels were increased during $2 \mathrm{~K} 1 \mathrm{C}$-induced hypertension. Data are mean \pm SEM values of the number of mice specified in table $2 .{ }^{*} \mathrm{p}<0.05,{ }^{*} \mathrm{p}<0.01$, compared to WT; ${ }^{\circ \circ} \mathrm{p}<0.01$ compared to control. C nNOS immunolabeling showed nNOS expression in macula densa (md) cells. The intensity of the labeling appeared slightly higher in the kidneys of Cx40-/- mice than in those of WT controls. $g \mathrm{l}=$ Glomerulus. Bar: $150 \mu \mathrm{m}$.

\section{Blockade of NOS Production Increases Hypertension in Cx40-/- Mice}

Three weeks after administration of L-NAME, blood pressure increased $(\mathrm{p}<0.001)$ both in WT and Cx40-/mice (fig. 5A) in parallel with a decrease in renin mRNA (table 2), COX-2 (fig. 5B), and nNOS mRNA levels (fig. 5C). Plasma renin levels (table 1) were only affected in $\mathrm{Cx} 40-/-$ mice. To assess the contribution of NO, we associated candesartan and L-NAME. To this end, when blood pressure of $\mathrm{Cx} 40-/-$ mice had returned to control values after a 2 -week treatment with candesartan, LNAME was added to the candesartan solution for another 2 weeks. This association increased the blood pressure
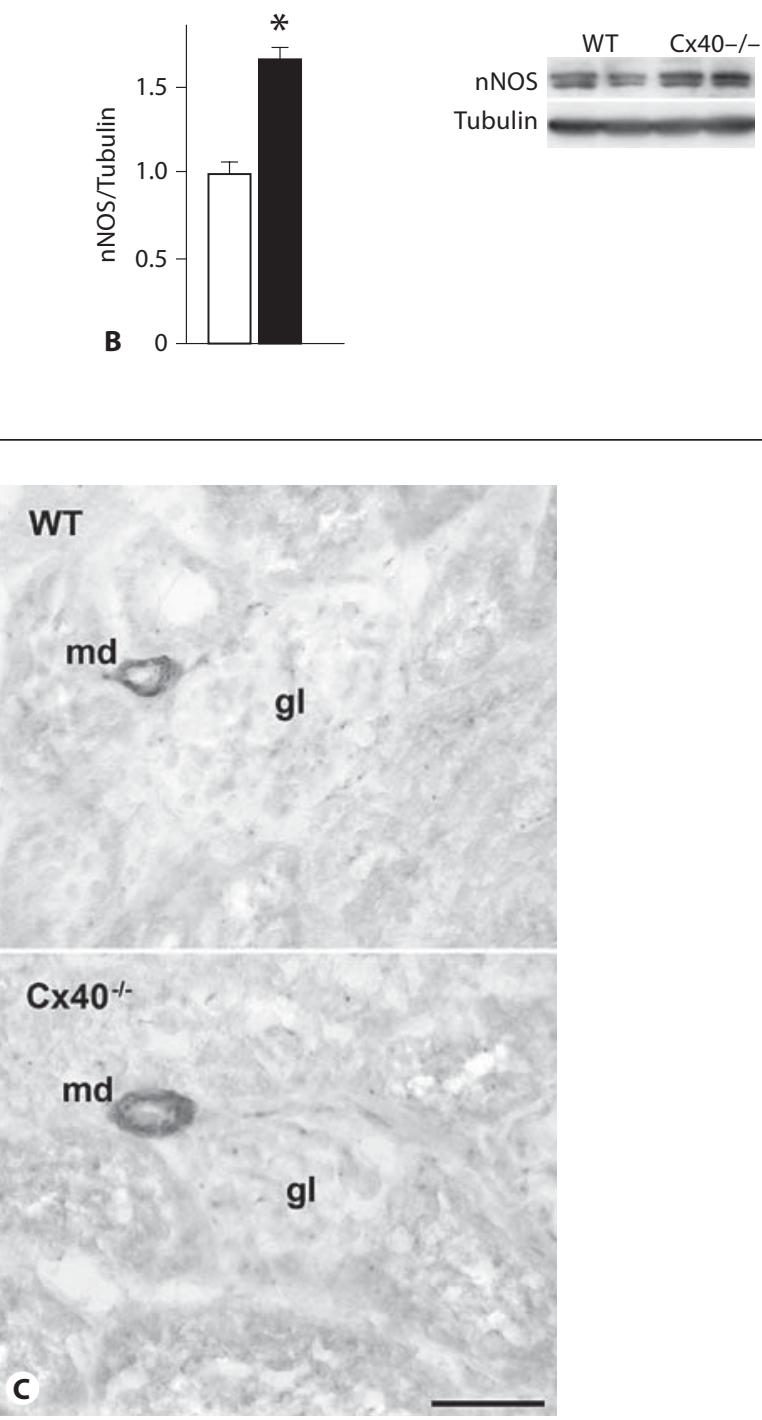

of WT mice and Cx40-/- mice $(\mathrm{p}<0.01)$ over the values observed after treatment with candesartan alone (fig. 5A). However, this increased blood pressure was lower $(\mathrm{p}<$ 0.05) than that observed in untreated Cx40-/- animals (fig. 5A). Compared to candesartan alone, the candesartan plus L-NAME treatment decreased renin mRNA to the levels observed in controls (table 2); it did not change the expression of renin and nNOS, and marginally decreased $(\mathrm{p}<0.05)$ COX-2 expression in WT mice (fig. 5B, C). In contrast, it decreased renin $(\mathrm{p}<0.05)$ and COX-2 $(\mathrm{p}<0.01)$, but not nNOS mRNA levels in Cx40-/- mice (fig. 5B, C; table 2). 

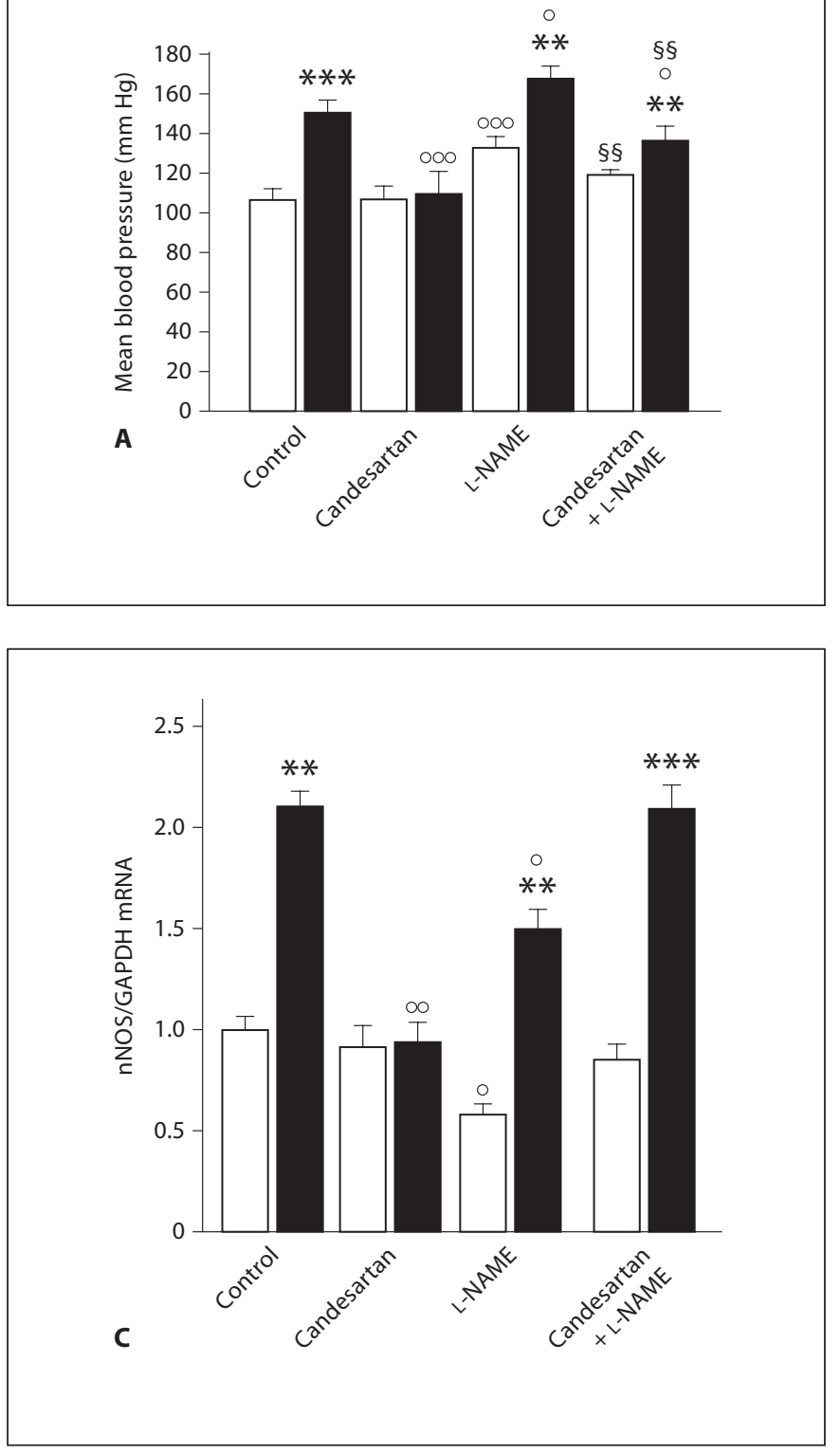

\section{Discussion}

Recent studies have demonstrated that the hypertension of $\mathrm{Cx} 40-/-$ mice is mostly due to increased numbers and function of the RSCs, which activate the renin-angiotensin system [36, 37]. In the absence of $\mathrm{Cx} 40$, the regulation of this system is altered both under a low-salt regimen and under conditions of changed renal blood flow, two situations sensed by different cell types of the JGA $[21,22]$. In the present study, we investigated the mechanism whereby loss of $\mathrm{Cx} 40$ leads to excessive renin secre-

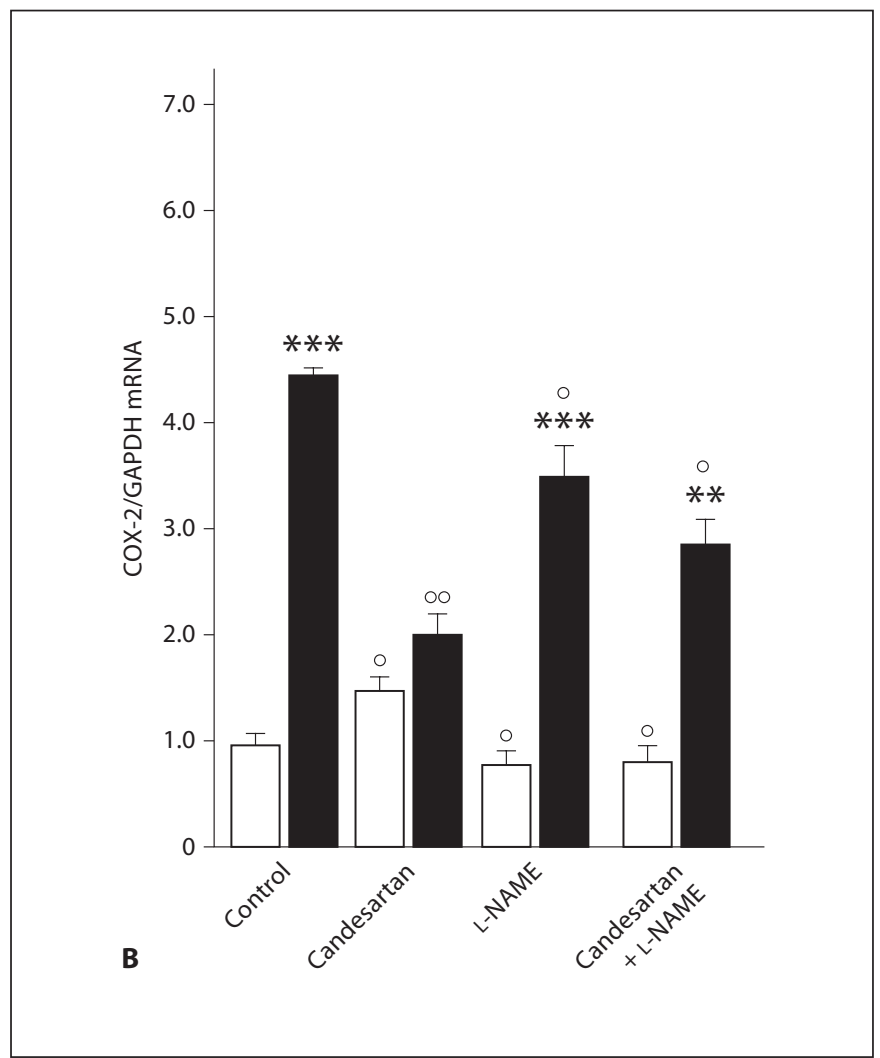

Fig. 5. Inhibition of NOS increased hypertension in $\mathrm{Cx} 40-/-$ mice. A Treatment with L-NAME increased blood pressure in both WT ( $n=10$; open bars) and Cx40-/- mice ( $n=10$; solid bars). This change was milder in both types of mice when L-NAME was associated with candesartan. B Both L-NAME and candesartan/ L-NAME treatments reduced the expression of COX-2 in WT and Cx40-/- mice. C nNOS expression was decreased in WT and Cx40-/- mice after the L-NAME treatment, but not when the drug was associated with candesartan. Data are mean \pm SEM values. ${ }^{* *} \mathrm{p}<0.01,{ }^{* * *} \mathrm{p}<0.001$, compared to respective $\mathrm{WT}$; ${ }^{\circ} \mathrm{p}<0.05,{ }^{\circ \circ} \mathrm{p}<0.01,{ }^{\circ 0 \circ} \mathrm{p}<0.001$, compared to respective control; ${ }^{\S} \mathrm{p}<0.01$ compared to treated animals.

tion by characterizing the involvement of the COXs and nNOS, the key enzymes of the macula densa, which are known to participate in the control of RSCs [13].

We first demonstrate that COX-2 is increased in $\mathrm{Cx} 40-/-$ mice, up to the levels observed in the hypoperfused kidney of $2 \mathrm{~K} 1 \mathrm{C}$ hypertensive mice. These findings indicate that prostaglandins play an adaptive role in the vascular response to hypertension in $\mathrm{Cx} 40-/-$ mice, and stress the parallel regulation of the renin and COX-2 genes, which accounts for the regulation of RSCs by the macula densa cells $[3,10,43]$. Since $\mathrm{Cx} 40-/-$ mice have 
lost the normal downregulating control of renin secretion in the presence of increased blood pressure [36] due to a still undetermined mechanism, we investigated the participation of prostaglandins, under the conditions of a pharmacologic blockade of COX activity. Inhibition of COX-2 by indomethacin did not change the levels of renin mRNAs in WT animals, suggesting that prostaglandins do not contribute to the basal regulation of the renin system. In contrast, the renin mRNA levels, which were about two-fold higher in the kidneys of untreated Cx40-/- mice, were normalized after indomethacin treatment. These observations are comparable to those of a recent report documenting that treatment of $\mathrm{Cx} 40-/-$ mice with the COX-2 inhibitors meclofenamate and SC58236 reduces renin expression to the control levels measured in untreated WT mice [44]. This study further showed that the COX-2 inhibitors markedly reduce the levels of the renin protein in the kidneys of $\mathrm{Cx} 40-/-$ but not WT mice [44]. Our measurements together with those of Wagner [44] show that indomethacin does not change the levels of circulating renin in either WT or Cx40-/- mice, consistent with the finding that COX-2 is particularly relevant for the ectopic expression of renin in periglomerular regions of $\mathrm{Cx} 40-/-$ mice [35], and not for renin secretion into the systemic circulation [44].

Treatment with candesartan increased the renal expression of COX-2 in WT mice, but decreased it in their Cx40-/- littermates, suggesting that the activation of macula densa cells by angiotensin II triggers the production of COX-derived prostanoids. In turn, prostanoids are expected to elicit a systemic vasodilatation, which presumably compensates the large increase in blood pressure resulting from excessive RSC function [1]. Strikingly, different salt diets, that affect renin and COX-2 expression in parallel in normal mice $[5,18]$, did not modify COX-2 expression in Cx40-/- mice, demonstrating that these animals do not properly regulate the expression of this cyclooxygenase in response to high angiotensin levels.

The renin-angiotensin system also contributes to the regulation of NOSs $[45,46]$. We have found that hypertensive mice featuring a selective increase in renin gene expression (table 2) also featured a significant increase in renal nNOS expression (fig. 4A). This change was observed in WT and Cx40-/- mice, and both in the clipped kidney, which was exposed to decreased blood pressure, and the contralateral kidney, which was subjected to higher systemic blood pressure. The upregulation in the nNOS gene in both kidneys of the $2 \mathrm{~K} 1 \mathrm{C}$ mice suggests that circulating angiotensin II plays a role in local renal
nNOS gene expression, and that the elevated blood pressure per se is not the primary factor responsible for the control of renal nNOS expression.

In the kidneys of $\mathrm{Cx} 40-/-$ mice, we found an increase in the expression of the nNOS isoform, which colocalizes with COX-2 in macula densa cells, as reported in WT animals [14, 47]. Pharmacological inhibition of NOS activity demonstrated that $\mathrm{NO}$ acts as a tonic stimulator of both renin and COX-2 expression in the kidney of both normal $[13,14]$ and $\mathrm{Cx} 40-/-$ mice. Thus, after treatment with L-NAME, Cx40-/- mice showed a markedly reduced renin mRNA and a milder decrease in circulating renin levels. The data imply that nNOS stimulates renin expression in $\mathrm{Cx} 40-/-$ and that the NO generated by nNOS or systemic eNOS activity [48] counteracts the excess of circulating angiotensin II in $\mathrm{Cx} 40-/-$ mice to prevent a further elevation of arterial pressure. The increased NO levels observed in Cx40 null mice therefore appear to participate in the adaptations of renal vessel to hypertension as observed in other models [49-51].

This conclusion fits with the antagonistic effects of angiotensin II and NO in the JGA, [52, 53], as well as with the crosstalk between these two regulators. Thus, it has been shown that angiotensin II induces the release of NO, which antagonized the contractile effect of angiotensin II on the afferent arteriole at the level of the JGA and its sensitizing effect on the tubuloglomerular-feedback mechanism [54]. This complex feedback is mediated by AT1 receptors on the angiotensin side and by cGMP levels on the NO side $[55,56]$. As a result, local NO production in response to an increased perfusion pressure inhibits renin release.

In summary, our findings demonstrate that the renal levels of COX-2 and nNOS are increased in mice lacking $\mathrm{Cx} 40$. Conversely, the reduction of prostaglandin synthesis by indomethacin was associated with a significant decrease in the blood pressure of $\mathrm{Cx} 40-/-$ mice which was paralleled by a decrease in the renal expression of renin but was not associated with a change in the circulating levels of the enzyme. These findings show that prostaglandins play an adaptive role in the response to hypertension in Cx40-/- mice, but are probably not involved in the mediation of the MD signaling that modulates renin secretion. In contrast, changes in nNOS levels may participate with those of eNOS to counteract the effects of the large excess of circulating angiotensin II in Cx40-/- animals as a result of abnormal renin production. 


\section{Acknowledgements}

Work of our teams was supported by grants from the Swiss National Science Foundation (310000-109530, 3100A0-100797 and 310000-109402), the Juvenile Diabetes Foundation Interna- tional (1-2007-158), the Octav and the Marcella Botnar Foundation, the Novartis Foundation, the Endocrinologie Genève Foundation, the Emma Muschamp Foundation, Novo Nordisk and the Geneva program on metabolic diseases.

\section{References}

1 Harris RC: Cox-2 and the kidney. J Cardiovasc Pharmacol 2006;47(suppl 1):S37-S42.

-2 Harris RC, Zhang MZ, Cheng HF: Cyclooxygenase- 2 and the renal renin-angiotensin system. Acta Physiol Scand 2004;181:543547.

-3 Hartner A, Cordasic N, Goppelt-Struebe M, Veelken R, Hilgers KF: Role of macula densa cyclooxygenase-2 in renovascular hypertension. Am J Physiol Renal Physiol 2003;284: F498-F502.

-4 Nasrallah R, Hebert RL: Prostacyclin signaling in the kidney: implications for health and disease. Am J Physiol Renal Physiol 2005; 289:F235-F246.

5 Harris RC, McKanna JA, Akai Y, Jacobson HR, Dubois RN, Breyer MD: Cyclooxygenase-2 is associated with the macula densa of rat kidney and increases with salt restriction. J Clin Invest 1994;94:2504-2510.

-6 Qi Z, Hao CM, Langenbach RI, Breyer RM, Redha R, Morrow JD, Breyer MD: Opposite effects of cyclooxygenase-1 and -2 activity on the pressor response to angiotensin II. J Clin Invest 2002;110:61-69.

7 Wagner C, Vitzthum H, Castrop H, Schumacher K, Bucher M, Albertin S, Coffman TM, Arendshorst WJ, Kurtz A: Differential regulation of renin and Cox-2 expression in the renal cortex of c57Bl/6 mice. Pflügers Arch 2003;447:214-222.

-8 Harris RC, Breyer MD: Physiological regulation of cyclooxygenase-2 in the kidney. Am J Physiol Renal Physiol 2001;281:F1-F11.

-9 Höcherl K, Wolf K, Castrop H, Ittner KP, Bucher M, Kees F, Grobecker HF, Kurtz A: Renocortical expression of renin and of cyclooxygenase- 2 in response to angiotensin II AT1 receptor blockade is closely coordinated but not causally linked. Pflügers Arch 2001; 442:821-827.

10 Castrop H, Klar J, Wagner C, Höcherl K, Kurtz A: General inhibition of renocortical cyclooxygenase- 2 expression by the reninangiotensin system. Am J Physiol Renal Physiol 2003;284:F518-F524.

- 11 Höcherl K, Kammerl MC, Schumacher K, Endemann D, Grobecker HF, Kurtz A: Role of prostanoids in regulation of the renin-angiotensin-aldosterone system by salt intake. Am J Physiol Renal Physiol 2002;283:F294F301.
12 Mann B, Hartner A, Jensen BL, Hilgers KF, Höcherl K, Krämer BK, Kurtz A: Acute upregulation of COX-2 by renal artery stenosis. Am J Physiol Renal Physiol 2001;280:F119F125.

13 Schricker K, Hamann M, Kurtz A: Nitric oxide and prostaglandins are involved in the macula densa control of the renin system. Am J Physiol 1995;269:F825-F830.

14 Cheng HF, Wang JL, Zhang MZ, McKanna JA, Harris RC: Nitric oxide regulates renal cortical cyclooxygenase-2 expression. Am J Physiol Renal Physiol 2000;279:F122-F129.

15 Cheng EY, Decker RS, Lee C: Role of angiotensin II in bladder smooth muscle growth and function. Adv Exp Med Biol 1999;462: 183-191.

16 Schricker K, Potzl B, Hamann M, Kurtz A: Coordinate changes of renin and brain-type nitric-oxide-synthase (b-NOS) mRNA levels in rat kidneys. Pflügers Arch 1996;432:394400.

17 Wolf K, Castrop H, Hartner A, GoppeltStrube M, Hilgers KF, Kurtz A: Inhibition of the renin-angiotensin system upregulates cyclooxygenase- 2 expression in the macula densa. Hypertension 1999;34:503-507.

18 Yang T, Singh I, Pham H, Sun D, Smart A, Schnermann JB, Briggs JP: Regulation of cyclooxygenase expression in the kidney by dietary salt intake. Am J Physiol 1998;274: F481-F489.

19 Castrop H, Kammerl M, Mann B, Jensen BL, Krämer BK, Kurtz A: Cyclooxygenase 2 and neuronal nitric oxide synthase expression in the renal cortex are not interdependent in states of salt deficiency. Pflügers Arch 2000; 441:235-240.

20 Schweda F, Friis U, Wagner C, Skott O, Kurtz A: Renin release. Physiology (Bethesda) 2007;22:310-319.

21 Schweda F, Kurtz A: Cellular mechanism of renin release. Acta Physiol Scand 2004;181: 383-390.

22 Mullins LJ, Bailey MA, Mullins JJ: Hypertension, kidney, and transgenics: a fresh perspective. Physiol Rev 2006;86:709-746.

23 Haefliger JA, Demotz S, Braissant O, Suter E, Waeber B, Nicod P, Meda P: Connexins 40 and 43 are differentially regulated within the kidneys of rats with renovascular hypertension. Kidney Int 2001;60:190-201.

-24 Haefliger JA, Nicod P, Meda P: Contribution of connexins to the function of the vascular wall. Cardiovasc Res 2004;62:345-356.
25 Sohl G, Willecke K: Gap junctions and the connexin protein family. Cardiovasc Res 2004;62:228-232.

-26 Ravier MA, Güldenagel M, Charollais A, Gjinovci A, Caille D, Söhl G, Wollheim CB, Willecke K, Henquin JC, Meda P: Loss of connexin36 channels alters beta-cell coupling, islet synchronization of glucoseinduced $\mathrm{Ca}^{2+}$ and insulin oscillations, and basal insulin release. Diabetes 2005;54: 1798-1807.

27 Klee P, Boucard N, Caille D, Cancela J, Charollais A, Charpentier E, Michon L, Populaire C, Peyrou M, Nlend Nlend R, Zuliano L, Haefliger J-A, Meda P: Connexin modulators of endocrine function; in Winterhager $\mathrm{E}$ (ed): Gap Junctions in Development and Disease. Berlin, Springer, 2005, pp 197-221.

28 Saez JC, Berthoud VM, Branes MC, Martinez AD, Beyer EC: Plasma membrane channels formed by connexins: their regulation and functions. Physiol Rev 2003;83:13591400.

29 Zhang J, Hill CE: Differential connexin expression in preglomerular and postglomerular vasculature: Accentuation during diabetes. Kidney Int 2005;68:1171-1185.

30 Haefliger JA, Krattinger N, Martin D, Pedrazzini T, Capponi A, Doring B, Plum A, Charollais A, Willecke K, Meda P: Connexin43-dependent mechanism modulates renin secretion and hypertension. J Clin Invest 2006;116:405-413.

31 Kirchhoff S, Nelles E, Hagendorff A, Kruger $\mathrm{O}$, Traub O, Willecke K: Reduced cardiac conduction velocity and predisposition to arrhythmias in connexin40-deficient mice. Curr Biol 1998;8:299-302.

32 Simon AM, Goodenough DA, Paul DL: Mice lacking connexin 40 have cardiac conduction abnormalities characteristic of atrioventricular block and bundle branch block. Curr Biol 1998;8:295-298.

-33 de Wit C, Roos F, Bolz SS, Kirchhoff S, Kruger O, Willecke K, Pohl U: Impaired conduction of vasodilation along arterioles in connexin40-deficient mice. Circ Res 2000;86: 649-655.

34 de Wit C, Roos F, Bolz SS, Pohl U: Lack of vascular connexin 40 is associated with hypertension and irregular arteriolar vasomotion. Physiol Gen 2003;13:169-177. 
-35 Kurtz L, Schweda F, de Wit C, Kriz W, Witzgall R, Warth R, Sauter A, Kurtz A, Wagner C: Lack of connexin 40 causes displacement of renin-producing cells from afferent arterioles to the extraglomerular mesangium. J Am Soc Nephrol 2007;18:1103-1111.

-36 Wagner C, de Wit C, Kurtz L, Grunberger C, Kurtz A, Schweda F: Connexin40 is essential for the pressure control of renin synthesis and secretion. Circ Res 2007;100:556-563.

>37 Krattinger N, Capponi A, Mazzolai L, Aubert JF, Caille D, Nicod P, Waeber G, Meda $P$, Haefliger JA: Connexin40 regulates renin production and blood pressure. Kidney Int 2007;72:814-822.

>38 Wagner C: Function of connexins in the renal circulation. Kidney Int 2008;73:547555.

-39 Gross V, Obst M, Kiss E, Janke J, Mazak I, Shagdarsuren E, Muller DN, Langenickel TH, Grone HJ, Luft FC: Cardiac hypertrophy and fibrosis in chronic L-NAME-treated AT2 receptor-deficient mice. J Hypertens 2004;22:997-1005.

-40 Okazaki H, Minamino T, Tsukamoto O, Kim J, Okada K, Myoishi M, Wakeno M, Takashima S, Mochizuki N, Kitakaze M: Angiotensin II type 1 receptor blocker prevents atrial structural remodeling in rats with hypertension induced by chronic nitric oxide inhibition. Hypertens Res 2006;29:277-284.
41 Wiesel P, Mazzolai L, Nussberger J, Pedrazzini T: Two-kidney, one clip and onekidney, one clip hypertension in mice. Hypertension 1997;29:1025-1030.

42 Haefliger JA, Polikar R, Schnyder G, Burdet M, Sutter E, Pexieder T, Nicod P, Meda P: Connexin37 in normal and pathological development of mouse heart and great arteries. Dev Dyn 2000;218:331-344.

43 Schricker K, Hamann M, Kurtz A: Prostaglandins are involved in the stimulation of renin gene expression in 2 kidney-1 clip rats. Pflügers Arch 1995;430:188-194.

44 Wagner C, de Wit C, Gerl M, Kurtz A, Höcherl K: Increased expression of cyclooxygenase 2 contributes to aberrant renin production in connexin 40-deficient kidneys. Am J Physiol Regul Integr Comp Physiol 2007;293:R1781-R1786.

45 Schricker K, Hegyi I, Hamann M, Kaissling B, Kurtz A: Tonic stimulation of renin gene expression by nitric oxide is counteracted by tonic inhibition through angiotensin II. Proc Natl Acad Sci USA 1995;92:8006-8010.

46 Castrop H, Schweda F, Mizel D, Huang Y, Briggs J, Kurtz A, Schnermann J: Permissive role of nitric oxide in macula densa control of renin secretion. Am J Physiol Renal Physiol 2004;286:F848-F857.

47 Tojo A, Onozato ML, Fujita T: Role of macula densa neuronal nitric oxide synthase in renal diseases. Med Mol Morphol 2006;39: $2-7$.

-48 de Wit C, Jahrbeck B, Schafer C, Bolz SS Pohl U: Nitric oxide opposes myogenic pressure responses predominantly in large arterioles in vivo. Hypertension 1998;31:787794.
49 Sigmon DH, Beierwaltes WH: Renal nitric oxide and angiotensin II interaction in renovascular hypertension. Hypertension 1993; 22:237-242.

50 Sigmon DH, Beierwaltes WH: Influence of nitric oxide in the chronic phase of two-kidney, one clip renovascular hypertension. Hypertension 1998;31:649-656.

51 Mount PF, Power DA: Nitric oxide in the kidney: Functions and regulation of synthesis. Acta Physiol (Oxf) 2006;187:433-446.

52 Schnermann J, Traynor T, Yang T, Arend L, Huang YG, Smart A, Briggs JP: Tubuloglomerular feedback: new concepts and developments. Kidney Int Suppl 1998;67:S40S45.

53 Navar LG, Inscho EW, Majid SA, Imig JD, Harrison-Bernard LM, Mitchell KD: Paracrine regulation of the renal microcirculation. Physiol Rev 1996;76:425-536.

54 Liu R, Persson AE: Angiotensin II stimulates calcium and nitric oxide release from macula densa cells through AT1 receptors. Hypertension 2004;43:649-653.

55 Schricker K, Kurtz A: Liberators of NO exert a dual effect on renin secretion from isolated mouse renal juxtaglomerular cells. Am J Physiol 1993;265:F180-F186.

56 Harrison-Bernard LM, Navar LG, Ho MM, Vinson GP, el-Dahr SS: Immunohistochemical localization of Ang II AT1 receptor in adult rat kidney using a monoclonal antibody. Am J Physiol 1997;273:F170-F177. 